\title{
Family Law and Welfare Policies: The Case for "Dual Systems"
}

\author{
Thomas P. Lewis* and Robert J. Levy**
}

\section{PROLOGUE}

$I^{\prime \prime}$ N A RECENT CONFERENCE on "The Extension of Legal Services to the Poor" a speaker observed that some legal aid societies insist that a person seeking a divorce first submit to reconciliation procedures. ${ }^{1}$ In the discussion that followed, a conferee insisted that a poor person should not be subject to a counseling requirement which the rich man could avoid with private counsel. Another suggested that counseling should be required of all who seek divorces irrespective of their economic status. ${ }^{2}$

It is becoming increasingly popular to analyze problems of the poor in this way-by drawing comparisons between the rich and the poor and cataloguing inequalities of one kind or another. The appeal for greater equality between rich and poor is a natural concomitant of the "Civil Rights Revolution" which can claim major judicial victories such as Brown v. Board of Education ${ }^{3}$ and Gideon v. Wainwright ${ }^{4}$ and major legislative-executive victories such as the Civil Rights Act of $1964^{5}$ and, indirectly, the War on Poverty. Equality as the central theme for argument, description, or analysis dramatizes and highights the status of the poor and carries a strong emotional appeal quite apart from any function it has as a legal command to action. Especially is this so today, for our society, which has always valued equality as an abstract ideal, shows an increasing willingness to conform its practices to its theories. Another factor contributing to the popularity of equality as a theme for argument is its apparent simplicity. Since equality is sought in the place of perceived inequality, the wisdom of rules or practices can be ignored; it is enough that one of two rules or practices be changed to conform to its counterpart. The conference session described above, for example, pro-

* A.B., 1959, LL.B., 1954, University of Kentucky; S.J.D., 1964, Harvard University. Professor of Law, University of Minnesota.

** A.B. 1952, Kenyon College; LI.B. 1957, University of Pennsylvania. Professor of Law, University of Minnesota.

1 Paulsen, The Legal Needs of the Poor and Family Law, in Conference Proceddings on the Extension of Legac Services to the Poor 18, 19 (U.S. Dep't of Health, Educ. \& Welfare 1964).

2 Conference Proceedings on the Extension of Legal Services to the Poor 68 (U.S. Dep't of Health, Educ. \& Welfare 1964).

3347 U.S. 483 (1954).

4372 U.S. 335 (1963).

578 Stat. 241 (1964) (codified in sections of 5 U.S.C., 28 U.S.C., and 42 U.S.C.). 
duced two contradictory suggestions, each one equal to the task of ensuring "equality" of legal services.

But the simplicity of equality as a standard is often more apparent than real. The problem of "inequality" that concerned the conferees resulted from the fact that legal aid society policies miglit differ from those of a private practitioner available for hire by the rich. This problem is not limited to divorce remedies-that simply happened to be the subject umder discussion. The reason assigned for attacking reconciliation procedures has equal force when applied to any divergence between the services of legal aid counsel and retained private counsel. If perfect equality is desired the only adequate remedy would be the provision of funds with which the poor might retain counsel of their own clroosing. But this remedy creates additional probleins of its own. It would not be a sensible allocation of resources to attempt to make legal services available to the supported group on demand. Whether individual retained counsel or group legal services are supplied, it is obvious that the lawyers involved or some agency will have to make judgments on the merits of the clains to be supported and pursued. ${ }^{6}$ Since the wealthy make their own clroices, at least a theoretical inequality would remain. The need to define the class to be provided funds for legal services presents a more difficult problem. Comparisons of legal services available according to economic status are usually drawn between the poor and the wealthy. The fact is, of course, that the bulk of our citizens are in neither category, but range across a wide spectrum between the extremes. It would very probably be impossible to define the benefited class and the claims to be funded in sucli a way as to avoid creating inequalities between members of the class and their fellow citizens on the next higher rung of the economic ladder. Resulting from a scheme premised on the eradication of inequality, these inequalities would be hard to justify.

None of this suggests that mandatory reconciliation procedures for legal aid clients are desirable or wise. There are differences of opinion on whether a family lawyer slould explore available avenues of reconciliation before proceeding with a divorce action. A private practitioner may make his own choice of policies, accepting or rejecting clients who are unwilling to abide by them. A rejected client, of course, has the choice of seeking other counsel who will accept the case on his terms. Because a legal aid client does not have this kind of choice, it is perfectly clear that legal aid lawyers cannot be permitted in all respects to exercise the independence of the nrost independent private lawyer. Some policies of general application should be adopted by the societies concerning the

6 The English have just grappled with this problem. See Iverson v. Iverson [1966] 1 All E.R. 258 (Prob.). 
kinds of services they will offer, and their attorneys will have to be willing to live with those policies. It should be equally clear, however, that within the framework of general policies set by a legal aid society, the lawyers must be provided leeway for professional judgment if they are to be worthy of their calling. ${ }^{7}$ Perhaps judgments about the worth of reconciliatory efforts in particular cases are the kind best left to the judgment of the lawyers involved, within the framework of any general policies established by the society. Whatever the outcome, legal aid societies should not be encouraged in the name of equality to provide the lowest common denominator of service available to the rich as a result of their ability to "shop" for counsel.

Equality is not a concept of fixed or easily identifiable value; its importance as well as its costs will vary with the circumstances to which it is applied. And these two variables-importance and cost-are not joined in a proportional relationship. If these characteristics are not borne in mind appeals to equality may be at best distracting, and at worst as full of false promise as the sweet singing of the sirens.

Equality is the touchstone of an important series of essays which provide the primary background for our topic-“"America's Dual System of Family Law." Professor Jacobus tenBroek's major work, California's Dual System of Family Law: Its Origins, Development, and Present Status, ${ }^{8}$ describes what he characterizes as two systems of family law, one for the poor and one for the rest of society. His purpose, especially in his discussion of the present status of California's family law, is to draw attention to the inequality he believes to be inlierent and inherently evil in the dual systems. Duality as sketclied by Professor tenBroek has several sources, but by far the most prolific is the system of welfare laws and rules which regulate participation by the poor in governmental aid programs. This system is contrasted with the civil family law of California, that is, the rules of law which govern family relationships in the rest of society. For example, he notes that certain resources of a wife in California cannot be reached by a person who has furnished "necessaries" to the husband, but that these same resources will be counted by the state when it determines the need of the family unit for public assistance. ${ }^{10}$ In the same vein, he complains that, while common law marriage is not recognized in California, the income of a man "assuming the

7 See Sparer, The Role of the Welfare Client's Lawyer, 12 U.C.L.A.L. REv. 361, 377-80 (1965).

8 (Pts. 1, 2), 16 Stan. L. Rev. 257, 900 (1964), (pt. 3), 17 Staw. L. Rev. 614 (1965)

[hereinafter cited as tenBroek with appropriate volume and pages].

9 tenBroek, 17 Stan. L. Rev. 614.

10 Id. at 623-24. 
role of spouse" will be considered by the state in determining the financial eligibility of the children in the houselold for welfare benefits. ${ }^{11}$ tenBroek's criticism of these and many other rules that govern the availability of welfare assistance is summarized in the following passage:

Family Law in California is not single, uniform, and equal as to all families whatever their status, condition, or wealth. On the contrary, it is dual and distinguishes among families on the basis of poverty. It is therefore discriminatory as to the groups which are the principal victims of poverty: racial and ethnic minorities, the economically, socially, and educationally underprivileged, children of broken homes, the aged, the physically and inentally handicapped. ${ }^{12}$

Professor tenBroek's articles are a prodigious, informative effort, containing many thoughtful criticisms of an existing welfare system with which we agree. Yet we have found it difficult to apply his mode of analysis to problems of family law and the poor. In part I of this article we explain our principal difficulties with Professor tenBroek's methodology. In part II we formulate and apply nore appropriate methods for analyzing family law doctrines and welfare policies.

\section{I \\ THE DISTRACTING SEARCH FOR DUALITY \\ A. The Constitutional "Neutrality" of Indigence}

The basic fault we find in Professor tenBroek's analysis is its designed capability of resolving important issues wholesale when a careful, particularistic analysis seems to be demanded. We believe this fault is traceable to conclusions drawn by tenBroek from assertions that poverty must be a constitutionally "neutral" factor. The constitutional under-pinning of his analysis appears more fully in the following passages:

Although the recipients of public aid programs are still effectively outside the jurisdiction of the United States Constitution, a new spirit in constitutional law has given positive signs of its future potential. In two lines of decisions the Supreme Court has furthered the right to equal justice. In the first, it upheld the right of the poor to appeal decisions whenever others can do so, and to have writs and records supplied free. In the second, it held that all criminal defendants inust have the aid of counsel, to be supplied free if they cannot afford to bear the costs. There can be no equal justice, the Court now holds, where the kind of trial a man gets depends on the amount of money he has. Welfare may take some departure and inspiration, too, from

11 Id. at 620 .

12 tenBroek, 16 Stan. L. Rev. at 978. 
Brown v. Board of Educ., a decision in another contested arena of public services-that of education. The issue in that case was over the arbitrary criterion of race used as a basis of segregation of the public schools. Is poverty a less arbitrary criterion when used as a basis of segregation in family law? The unexcelled rhetoric of $\mathrm{Mr}$. Justice Jackson in Edwards v. California . . . is directly in point:

"Does 'indigence' as defined by the application of the California statute constitute a basis for restricting the freedom of a citizen, as crime or contagion warrants its restriction? We should say now, and in no uncertain terms, that a inan's mere property status, without more, cannot be used by a state to test, qualify, or limit his rights as a citizen of the United States. 'Indigence' in itself is neither a source of riglits nor a basis for denying thein. The mere state of being without funds is a neutral factconstitutionally an irrelevance, like race, creed, or color."

...

When "the mere state of being without funds is a neutral factconstitutionally an irrelevance"; when classifications based on poverty and handicap are measured by equal protection standards of constitutional purpose and proper classification; when constitutional riglits cannot be sacrificed as a condition of granting public assistance; when law enforcement and penal intrusions into the law of welfare are fully restrained by the fourth, fifth, and fourteenth amendinents; when free movement is recognized as a constitutional right forbidding residence restrictions in welfare; when the highest court in the land as well as the highest court in California see responsibility of relatives provisions as arbitrary and discriminatory taxation; when welfare categories and constitutional classifications coincide; when the granting and withholding of assistance and the variation of requirements among and between programs are subjected to due process and equal protection norms; when a presumption of competence and responsibility.of clients becomes a welfare counterpart of the criminal law presumption of innocence-when these things happen, then indeed will the law of the poor feel the full impact of the pronouncement that "separate" is "inherently unequal," generating among aid recipients "a feeling of inferiority as to their status in the community that may affect their hearts and minds in a way unlikely ever to be undone." Until that time, however, California's separate, different, and unequal system of family law of the poor will continue in force basically in the form in which [the Elizabethan poor laws] ... gave it to England and the Englishspeaking world. ${ }^{13}$

Everyone must agree that "classifications based on poverty and handicap [should be] measured by equal protection standards of constitutional purpose and proper classification," and that "constitutional rights should not be sacrificed as a condition of granting public assistance." tenBroek's larger thesis, however, is reflected in the three pas-

13 tenBroek, 17 StaN. L. Rev. at 681-82. (Emphasis added.) 
sages we have italicized above to the effect that "separate" is "inherently unequal," that poverty is always an arbitrary criterion for action in the same sense that race is, and hence, that dual systems of law, as he has characterized them, are inherently discriminatory.

In considering the soundness of these contentions, the full meaning of Mr. Justice Jackson's statement in Edwards, ${ }^{14}$ quoted above, must be borne in mind. First, it must be remembered that Jackson's $\mathrm{s}_{\vartheta}$ opinion was prompted by the majority holding in Edwards that the interstate movement of persons is "commerce." The whole of his opinion is dedicated to the proposition that interstate travel and taking up residence within a state are rights of national citizenship, protected from infringing state action by the fourteenth amendment. Most of Jackson's language is expressly directed to a consideration of the rights of national citizenship; all of it is uttered in that context. If Jackson meant that indigence must have no effect on one's claims to the rights of national citizenship, he was very likely correct. Since citizenship itself does not in any way depend on economic status, rights which inhere in citizenship should exist independently of the citizen's economic status.

The rights which inhere in national citizenship are not many, and it is probable Jackson intended his concept of neutrality to have a broader application than this. He says in a later passage that the possession of property must not be a pretext for unequal or exclusive civil rights. Apphication of his quoted language in this context is not difficult. Freedom of speech, freedom from unreasonable searches and seizures, ${ }^{15}$ the privilege against self-incrimination, and the right to counsel, ${ }^{16}$ for example, will not be granted or withheld on the basis of indigence. The economic status of an individual simply has no relevance to the purposes served by these rights and privileges. Beyond this kind of application, the validity of Jackson's rhetoric is more doubtful. If he meant that indigence is a neutral fact in the same sense that race or color would be regarded as a neutral fact in 1966, he was almost certainly wrong.

A truly neutral fact-one which is "constitutionally an irrelevance"can be "neither a source of rights nor a basis for denying them." Race

14 Edwards v. California, 314 U.S. 160, 184-85 (1941).

16 "Midnight welfare searches" have not yet been ruled invalid, but no one would contend that application of the exclusionary rule announced in Mapp v. Ohio, 367 U.S. 643 (1961), could be made to turn on the economic status of a defendant.

10 It can be argued in one sense that the right to counsel established in Gideon v. Wainwright, 372 U.S. 335 (1963), depends upon a defendant's economic status. The sixth and fourteenth amendments guarantee the assistance of counsel to all defendants in "criminal prosecutions." If a defendant is unable to afford counsel governnent must provide counsel for him, but this right is based on the individual's status as a defendant in a criminal prosecution, not "indigence in itself." 
and color very probably meet this test. ${ }^{17}$ Indigence is not yet the source of a right to demand benefits, supported by a correlative governmental duty to provide them. But no one can doubt that government may choose to create certain benefits and make them available only to the indigent; too much governmental action is based on the essentially unchallenged assumption that it may. At this point it might be contended that rehance upon the neutral fact terminology is more limited-the central concern is not with benefits but detriments, and poverty is a neutral fact where detriments are to be imposed.

This argument oversimplifies in at least two ways the problems with which this article is concerned. For one thing it assumes that the difference between benefits and detriments can be put to a litmus paper test. Benign quotas, as their name imphes, are presumably desigued by wellintentioned people desiring to help Negroes or other minorities, but reasonable men might differ in their characterization of the quotas as beneficial or detrimental. ${ }^{18}$ In the same way, some schemes apparently designed to benefit the poor arguably may be detrimental to them. Suppose a school system develops a special curriculum for school districts containing large numbers of children from low-income families. Assuming the purpose of this effort to be beneficial, its classification as beneficial or detrimental nevertheless presents difficult questions. In any event, if "neutrality" is a two-sided coin, we must at least recognize that power must reside somewhere to decide which side of the coin is presented in particular cases. This necessity is one very good reason for regarding race and color as wholly neutral facts.

Secondly, once it is assumed that benefits can be granted on the basis of indigence, another factor-governmental programs providing benefitsmust also be considered. Governmental spending programs are necessarily developed to accomplish purposes. Conditions must be established to ensure that expenditures will be consistent with program goals. For example, certain grants of public money might be tied to a vocational training program. An individual desiring to participate in the program will have to conform to the requirements of the program. Programs desigued to assist dependent children must include minimum conditions to ensure that the financial assistance reaches the needy children. In any program developed to assist the indigent, "indigent" will have to be

17 This is not to say necessarily that race can never influence the decision-making process of government. See Fiss, Racial Imbalance in the Public Schools-The Constitutional Concepts, 78 Harv. L. REv. 564, 574-83 (1965). The constitutional neutrality of race has not been authoritatively established. See Kurland, The Supreme Court 1963 TermForward, 78 HARv. L. Rev. 143, 146-48 (1964).

18 See Bittker, The Case of the Checkerboard Ordinance: An Experiment in Race Relations, 71 YALE L.J. 1387 ,(1962). 
defined in terms of income as well as in terms of the unit of personsindividual or family-whose income is determinative. Ideally these rules or conditions will be developed to help secure the ends for which spending programs are designed; the rules will not be created simply to subject persons to particular treatment because they are indigent.

In addition to the conditions necessary to direct particular money towards particular ends, we know that programs designed for beneficial purposes often have unplanned, certainly undesired, latent consequences which require offsetting regnlations. ${ }^{19}$ For example, a negative income tax program based on total family income may encourage some young people to avoid formal marriage so that the "husband's" income will not lessen the fannily's total benefit. If the legislature decides that this encouragement should be removed in order to promote fairness to all, special rules will be required. Again, as in the case of purposive conditions, the needed rules will be responsive to problems connected with the spending program; they will not be designed simply to treat the indigent differently from the affuent.

These conditions and rules are the sources of much of the so-called "law of the poor." Because they are built into programs designed to benefit the poor and because their application does not turn on the existence of "indigence in itself," neither a benefits-detriments nor a "separate is inherently unequal" analysis is adequate to the task of formulating wise policy or sound answers to questions posed in constitutional terms.

\section{B. Family Laws and Welfare Policies}

The importance of recognizing that the great bulk of rules in welfare administration relate to governmental welfare programs and not to classifications based on "indigence in itself" cannot be overemphasized. Whether tenBroek's purpose in developing the theme of equality is to bring his case within the equal protection clause of the Constitution or simply to appeal to the philosophical ideal of equal justice under lawthe like treatment of like cases-it is necessary to determine whether particular situations present "like" or different problems. This inquiry is missing (or supplied by assertion) in most of his analysis, an approacl reflected in his characterization of the two systems of law to be compared as "dual systems of family law." Of course one system is the family law and the other, as evidenced by its source, is the welfare law of society. Labels are not necessarily meaningful, but the different sources of the law represented by our labels indicate the possibility that important differences of purpose may underlie specific rules in the two systems. A refusal to

18 See Beld, Am to Dependent ChILDRen vii (1965). 
inquire into this possibility results in an analysis that is more distracting than helpful to those who seek to evaluate particular rules and policies.

This is exemplified in tenBroek's discussion of "dual" concepts of property relations law between husband and wife. He sketches California's community property rules, noting that, while property "acquired by the labor or skill of either partner during the continuance of the partnership [marriage] belongs to both of them,"20 eacli partner "may have property in which the other lias no interest."21 Describing the mutual obligations of support between husband and wife under the civil law, he writes:

According to the Civil Code, the obligations of mutual respect, fidelity, and support which the marital partners assume are matters about which they "contract towards each other." The terms of the "contract" about support, lowever, are also established by the Civil Code. The obligations are mutual but not identical, those of the husband being the more compreliensive and also penally enforceable. Thus the husband must support the wife if he has "sufficient ability ... or . . . is able to earn the means" to do so "unless by her misconduct lie was justified in abandoning her." The wife must support the husband "wlien he has not deserted lier ... and he is unable, from infirmity, to support himself." In addition, the interspousal support obligation is stated in terms of a civil remedy for the third-person creditor who has met the need. Good faith suppliers to the wife of "articles necessary for lier support" can "recover the reasonable value thereof from the husband." The earnings of the wife and some of her separate property are liable for the payment of debts contracted by the husband or by the wife for the necessaries of life furnislied to them or either of them while they are living together. In contrast, property of the wife held by her at the time of the marriage or acquired afterward by devise, succession, or gift (other than by gift from lusband), is not so liable. ${ }^{22}$

The family law of the poor is differentiated:

As it emerges from the Califorma Welfare and Institutions Code in implementive administrative material, the family law of the poor reflects a different conception of the marital rights and duties relating to property and support. Husband and wife are not seen as semi-independent partners, standing in a contractual relationship to each other, and maintaining distinct interests in community income and property; they are viewed rather as a single, mtegrated entity, having a single, undivided, and unseparated interest in a common pool of family resources derived from the income and property of both spouses. Withdrawals from the common pool miglit, indeed must, be made by both to meet the costs of living. The family law of the poor, by contrast with the civil family law, puts greater emphasis upon the community, less

20 tenBroek, 17 Sran. L. Rev. 622.

21 Id. at 623 .

22 Ibid. (Footnote omitted.) 
upon the individuals; greater emphasis upon meeting the needs of both spouses for support, less upon their individual rights to separate property and income. ${ }^{23}$

Thus California law regulates the obligations of support and property rights as between husband and wife, including the rights of third parties who furnish necessaries to one spouse or the other, but the rules change in detail when the state is the third party called upon to assist in the support of one of the spouses. For example, a third party supplier of necessaries to the husband can make no claim against property of the wife which she has brought to the marriage, but the state will look to such property as an available family resource in determining need for public assistance. Do these provisions create a dual system of family law or discrete systems of family law and welfare policies? Under the family law third parties supplying necessaries to a husband, poor or rich, have no claim against inherited property of the wife. Under the welfare law, government will consider the inherited property of the wife in determining the need of any husband who applies for public assistance. It is true that this latter rule will have no relevance for a lrusband who has no need for public assistance, but neither will the rule that makes assistance available on the basis of need. And a means test surely does not create an inherently discriminatory duality; as most rules of law, including these under discussion, it simply lias inclusive and exclusive features. Consider the rules imposing liability on persons who negligently injure others. Persons who accidentally injure others are not liable simply because their situation is not covered by the rules. In deciding to treat a negligent person differently from a nonnegligent one, the state must not be arbitrary; but difference of treatment merely introduces a need to show an absence of arbitrariness, it does not carry its own proof of arbitrariness. The dual systems of law analysis stops just at the point when, for us, it has posed questions which need further analysis: What resources slrould be taken into account when the need of a family or a member of a family for governmental assistance is considered? Slould government ignore the inherited wealth of a wife when considering the need of her lrusband for assistance by the rest of society? If it is determined that government should count a wife's inherited wealth as a family resource at the point when all of society is called upon to assist a family member-specifically the husband-does it follow that the family law sloould or must give to all lrusbands automatically and in all circumstances claims to the inlerited wealth of the women they marry?

Since welfare policies must be developed in the context of an existing

23 Id. at 624 . 
society and legal structure, it is apparent that family laws and notions held by society about family relationships and family life may have a quite important bearing on these policies. But the dual systems analysis often supplies the wrong clues to the precise relevance of the one system to the other. This shortcoming is borne out by analysis of two controversial welfare policies-those attaching important consequences to the presence of a "man in the house," and those creating or recognizing relative support obligations.

In discussing the welfare policy concerning the "man in the house" it will be convenient to refer to California's rule which is criticized by tenBroek. In the California Welfare and Institutions Code an obligation of support for a woman's children is imposed in terms upon a male hiving with the woman and assuming the role of spouse, if without his support the children would be needy and eligible for AFDC. ${ }^{24}$ The courts have not yet interpreted this provision to mean more than that his income may be taken into account in determining the need of the family for purposes of public assistance. ${ }^{25} \mathrm{~A}$ dual system of family law results because "while there are no common law husbands under the Civil Code . . . by illicit cohabitation with a man, the mother of needy children, under the law of the poor, acquires a community property interest in his income." ${ }^{20}$ If the law simply discriminated between rich and poor, turning the application of the common law marriage doctrine on the economic status of the parties without more, tenBroek would have a strong case for condemning the resulting duality. But economic status alone is not the factor governing the application of the "man in the house" rule, and in any event, the "man in the house" rule is not a common law marriage doctrine. The comparison drawn by tenBroek comes down to a comparison between a man living with a mother who seeks public assistance for her children and a man living with a mother who does not need or seek such assistance. Neither man has a legal obhgation to support the mother's children, and each is presumably free to sever the relationship, at the same time being subject to the woman's power to sever the relationship. Practically speaking the "community property interest" of the needy children's mother in her mate's income represents nothing more than the choice she must make when seeking AFDC between severing the relationship or maintaining the relationship and having his income counted as family resource. If he is unwilling to share his income to

24 Cac. WeLFare \& INST'NS CODE § 11351.

25 People v. Owens, 231 Cal. App. 2d 691, 42 Cal. Kptr. 153 (1965); County of Kern v. Coley, 229 Cal. App. 2d 172, 40 Cal. Rptr. 53 (1964); People v. Rozell, 212 Cal. App. 2d 875, 28 Cal. Kptr. 478 (1963).

26 tenBroek, 17 Stan. L. Rev. 620. 
the extent it reduces an AFDC allotment, she has a financial incentive to sever the relationship.

Under the family law of California no similar financial wedge threatens to part the unmarried couple. It is worth noticing, however, that the creation of one by the pohicymakers would satisfy objections based on duality. Still, there are reasons to believe this is not the crux of the problem. In the first place, it is difficult to conceive of the means by which nearly equal pressures could be brought to bear on men outside the context of public assistance. Since the relationship in either the welfare or nonwelfare context is only as permanent as the parties wisl it to be, there is no reason to believe a mere rule of law creating an obligation of support would have significant effect. Secondly, there is no reason to believe that the couple seeking public assistance would derive any satisfaction from knowing that equality of position had been created as nearly as possible between them and others not seeking public assistance but otherwise similarly situated. Finally, and perhaps this follows from the first two observations, the "man in the house" rule ought to be judged on its merits before we accept any solution designed merely to create equivalence between welfare policy and particular family laws.

We believe that family laws, or family relationships, are relevant to an evaluation of the "man in the house" rule, but not the "family" or family law chosen for purposes of comparison by tenBroek. The "man in the house" rule is a derivative of society's organization around the married family. Because of this organization and because need is an essential test in most plans of public assistance, the income of a married father is necessarily considered in determining the need of his family for assistance. Usually the income of stepfathers is similarly considered. In the absence of a "man in the house" rule of some kind, different treatment would be accorded the income of some fathers and "stepfathers" resembling their married fellows in all respects except the existence or validity of a marriage ceremony between them and women with whom they are hiving. It is the availability of governmental assistance that makes this different treatment important enough to consider the need for an off-setting regulation. In short, the problem to which a "man in the house" rule ought to be addressed is one that springs from the creation of a welfare program geared to family units. It is in this context that the rule should be evaluated. In part II we consider the merits of a "man in the house" rule in this larger context.

A different kind of relationship between society's notions about the family and particular welfare policies is illustrated by rules creating relative support obligations. But again a dual systems analysis fails to disclose the relationship. For purposes of illustration, assume that the 
state has a simple rule requiring financially able children to contribute to the support of a needy parent who has applied for welfare benefits. If this is the only rule of law in the jurisdiction establishing obligations running from adult children to their parents, the children of self-sufficient parents will have no obligation to their parents while the children of poor parents may have an obligation. An argument can then be made that there are two systems of family law. ${ }^{27}$.

But nothing is gamed by viewing the problem this way. There are two classifying factors in the rule, the need of parents and the economic status- the ability to contribute support-of the children. Since poor children will have no obligation even if their parents are needy, while well-to-do children will have an obligation, any discrimination on the basis of the one factor favors the poor children. The other classifying factor-the need of the parents-is surely a rational one, perhaps the only rational one that could be used in light of the purpose of the rule. Until the need of parents is established there is little reason for society to be concerned about the obligations, if any, which children should have toward their parents. And an application for public assistance, which today is widely available, is not an irrational mechanism for determining a parent's need. If the rule of relative support is unwise or unconstitutional, then, it must be because considerations other than discrimination against the poor, as such, militate against the creation of obligations running from adult children to their parents.

It is when rules of relative support are evaluated on their merits that notions about family relationships become relevant. In fact, if there is any support for schemes of relative responsibility, it will be found in these notions. If we look for a moment at the laws of descent and distribution, or at the definitions of "dependents" in many workmen's compensation provisions governing death benefits, the role of family relationship is quite apparent. For purposes of distributing a decedent's property a distant relative will be selected as a beneficiary in preference to the state or, needless to say, a stranger. A parent who was partially

27 As a matter of fact, both the civil family law and the "family law of the poor" in Cahifornia contain requirements that adult children help support their indigent parents. In dealing with relative support problems, tenBroek analyzes a variety of relative support rules on the basis of a variety of considerations, including due process, equal protection, and social policy. His equal protection analysis is, for the most part, traditional in scope, taking into account the rationality, if any, of a differentiation between the adult child or other relative of an indigent person and the general public for purposes of attaching an obligation to support the indigent person. He adds a "dual systems" analysis in which he cluaracterizes relative support laws as "Iaws of the poor" that discriminate against the poor. tenBroek, 17 StAN, L. Rev. 644. Since we are dealing only with this aspect of the problem at this time, we have tried to isolate it by using a simplified illustration. 
supported by a decedent workman will in many states be entitled to a compensation benefit partially replacing the lost source of support. Similar treatment may not be accorded a nonrelative supported by a workman. Of course these laws do not deal with precisely the same problem as the one of designating the persons who should be obligated to support another person during his hife. We expect the public at large to react differently to the intestacy laws that favor a nephew than to a rule that requires a nephew to support an indigent uncle. But it is still sensible to ask whether there are degrees of relationship that should be the basis of a support obligation. And the answer inevitably will depend, in part, on the attitudes that have evolved concerning the "family" with respect to other problems.

At the outset, we said that tenBroek's articles contain many "criticisms of an existing welfare system with which we agree." Our difficulty with his unifying theme does not lead us to disagree necessarily with other objections he registers or with certain remedies he proposes. Particular rules or policies as administered may be thoroughly objectionable for reasons unrelated to "dualism" as the concept is used by tenBroek. For example, in many relative support schemes, guidelines concerning amounts of contribution and the ability of children to contribute often are not clear, vesting dangerous discretion in welfare officials. Support obligations vary, often without rhyme or reason, according to the category of public assistance involved. Some programs of assistance, forced commitments of persons to mental institutions for example, are hardly distinguishable from many tax supported programs of institutional assistance or service. An adult child may be compelled, iromically, to support a parent who deserted him as a child. In an extensive analysis of California's crazyquilt system of relative support obligations Professor tenBroek lays bare an imposing array of questionable policies and procedures. ${ }^{28}$ Welfare policies and rules should be subjected to this kind of analysis. But we beheve characterization of the rules as sources of dual systems distracts from the needed effort.

\section{II}

A DUALISTIC ANALYSIS OF FAMUIY SUPPORT OBLIGATIONS-STEPFATHERS AND "THE MAN IN THE HOUSE"

By statute or administrative regulation, a number of states have attached "substitute parent" policies to their AFDC programs. The

28 tenBroek, 17 Stan. L. REv. 629-46. His analysis includes an appraisal of Department of Mental Hygiene v. Kirchner, 60 Cal. 2d 716, 388 P.2d 720, 36 Cal. Rptr. 488 (1964), vacated and remanded, 380 U.S. 194, decision on remand, 62 Cal. $2 \mathrm{~d}$ 586, 400 P.2d 321, 43 Cal. Rptr. 329 (1965), which held the relative support provisions in the state's mental illness programs unconstitutional under the state's equal protection clause. 
typical provision denies benefits to any child whose mother is married to, or is maintaining a continuing family relationship with, a man whose income exceeds the relevant assistance eligibility standard. ${ }^{20} \mathrm{We}$ do not discuss provisions which deny benefits because of the mother's out of wedlock sexual behavior; such statutes raise issues comparable to other "suitable hone" criteria. ${ }^{30}$ Our concern is with stepfathers and with stable but informal (or invalid) family relationships. In the sections which follow, we explore the considerations which should be taken into account, first, in devising family law "substitute parent" support policies, and, second, in determining whether governnent financial assistance should be given to children whose families include a solvent "substitute parent."

\section{A. Family Law}

\section{Stepfathers}

Very few states impose child support obligations on stepfathers. ${ }^{\mathbf{3 1}}$ Almost universally, the legislature focuses on the natural father: $\mathrm{He}$ is required to support the child while the marriage subsists ${ }^{32}$ and after the marriage has been terminated by divorce. ${ }^{33}$ The mother often has a secondary obligation during and after the marriage. ${ }^{34}$ The father is relieved of his support obligation only when he is completely divested of parental "rights" and "duties"-when another father adopts the child. It is not unlikely that the stepfather's exemption from support responsibility reflects ancient notions of the sanctity of blood ties and the indissolubihity of marriage rather than any contemporary examination of the social values at stake. Yet statutory nodiflcations will be difficult to accomplish. No legislator will enthusiastically depart from an historically determined doctrinal framework built upon an emotionally appealing, if simplistic, foundation: Since the natural father brought the children into the world, let him pay for thenr. Nonetheless, we have attempted a rational assessment and accommodation of the competing values. We believe that stepfathers should be encouraged to support their children. The need for legislation does not seem imperative, however, and a statute imposing a support obligation on stepfathers would produce a new series of difficult social and legal problems. We conclude, therefore, that the current doctrinal framework should be retained; stepfather support of the family

\footnotetext{
29 See BEIr, op. cit. supra note 19, at 76-92.

$30 \mathrm{Id}$. at 85-86. See also text accompanying note 83 infra.

31 Madden, PERsons and DoMestic Reiations 390 (1931).

32 See Foote, Levy \& SANDER, Cases on Fammy Law 308 (1966).

33 Id. at $918-24$.

34 See, e.g., Omio Rev. Code AnN. $\$ 3103.03$ (Page 1950).
} 
should be achieved by means of informal family processes rather than the compulsion of a statutory obligation.

It will be helpful, initially, to identify the several interests which must be taken into account in determining the scope of the stepfather's support responsibility. The child obviously has an important stake in the decision. His physical well being, his social and intellectual development, perhaps even his enıotional stability, require continuing financial assistance. The child's mother should not have sole responsibility to provide for his needs-her earning capacity is himited; in any event, there is general agreement that the child benefits if the mother can choose not to work in order to devote her time and attention to him. The child also has an interest in the security provided by an intact and stable family; the child's need for these values is likely to be great, since he has been subjected to a severe enotional strain-his parents' divorce or his father's death -and to some period during which he has had to rely exclusively on his mother for care, protection, and discipline. In addition, the child who is no longer an infant may profit from a continued relationship with his natural father-if the relationship can be nuaintained without sacrificing other values. The natural father-even if he has reniarried and acquired a new family - has a counterpart interest in nuaintaining a relationship with the child. At the same time, the natural father, especially if he has remarried, has an interest in shifting support responsibility to the stepfather. The stepfather's interests, on the other hand, may be inconsistent with the natural father's. Because the stepfather becomes the head of the new family, eliminating, or minimizing, the "parenting" role of the natural father would be to his advantage. The stepfather will probably be a better father for the child (he will certainly have less personal anxiety about his role and his authority) if the natural father cannot second-guess his decisions; and the stepfather can expect the child to adjust to the new family unit nore quickly if he is the sole paternal decision-maker. The stepfather also lias an interest in avoiding any permanent responsibilities to his wife's children if the marriage is a failure, unless he has voluntarily assumed then by adoption. Finally, the mother has an interest in maximizing her reniarriage opportunities; when slie lias remarried, she shares the stepfather's interest in the new family's cohesiveness. ${ }^{35}$

\footnotetext{
${ }^{35}$ We are not concerned here with the stepfather's hability to third parties to whom the child may become obligated during the marriage. Merchants might be protected without enactment of a statutory support obligation. If the mother makes purchases for the child's benefit, the stepfather could be held liable either by applying the common law "necessaries" doctrine, MADDEN, op. cit. supra note 31 , at 195 , or by liberally interpreting a "family
} 
Assigning priorities among these interests is much more difficult than describing them. Value choices have to be made without basic information about the behavior we are trying to influence; and we will have to rely on assumptions as to the likely effects of alternative policies. For example, a substantial number of California legislators argued that imposing a support obligation on the stepfather "would discourage men from marrying women with children and thus deter re-establishment of normal parental, family and home relationships for the children." ${ }^{\text {"b }}$ Yet there is no reliable evidence that prospective stepfathers would be deterred by a modification of current support doctrines. Indeed, unless the mother is receiving monthly payments from the natural father, many prospective stepfathers may believe that stepfathers now have a legal duty to support their stepchildren. We know that most divorced women remarry $^{37}$ despite the fact that many natural fathers do not honor their support obligations. ${ }^{38}$ The only hypothesis which seems warranted concerns behavior after the marriage talses place; although many stepfathers and mothers choose a standard of living in reliance upon the natural father's continuing support payments, most stepfathers will probably support their stepchildren no matter what the statutes require:

Quite regardless of the presence or absence of legal liability, most stepfathers do support their stepchildren. As a practical matter, they can hardly avoid it. They all live under the common roof, view the

expense" statute: "statutes ... declaring that the husband and wife shall be jointly liable for family expenses, such as necessary food, clothing, education of the children, etc." Id. at 200. If the child makes the purchase, although the stepfather may have no statutory duty, "if he voluntarily assumes the obligation of support, by receiving the children into his family and assuming to stand in loco parentis to the children, he is liable." Id. at 390 . Finally, the stepfather's responsibility can be established by traditional agency principles. Id. at 391-92. (1954).

36 tenBroek, The Impact of Welfare Law Upon Family Law, 42 CaLIF. L. Rev. 458, 479

37 In the age ranges of $25-35$, when most women would have young children, the estimate of divorced women who remarry was well over minety per cent. JACOBSON, American Marriage and Divorce 85 (1959), cited in Foote, Levy \& Samder, op. cit. supra note 32 , at 773 .

38 Foote, LeVY \& SANDER, op. cit. supra note 32 , at 938 , reporting data derived from Kapian, Surport From Absent Fathers of Chimdren Receiving ADC 1955, at 7, 15, 24-26 (U.S. Bureau of Public Assistance Rep. No. 41, 1960) (support awards in forty-two per cent of the families; support actually received in only about half of these cases, and in only $18.3 \%$ of total cases). These data relate to court awards of support rather than to separation agreements negotiated by the parties-a much inore common method of settling financial affairs among middle and upper-class divorced couples. There is no information concerning the extent to which middle and upper-class natural fathers perform their decree or separation agreement obhigations. 
common television and the stepchildren cannot very well be driven from the table when the parents and other children are eating. ${ }^{39}$

The difficulties in accommodating the interests we have outlined are compounded because any support rule will have to be applied in a great variety of contexts. A statutory policy suited to poor natural fathers and rich stepfathers may look much less sensible if the natural father is the affluent one; a rule which reflects, and deals adequately with, the expectations and behavior of middle-class natural and substitute parents may not take adequate account of behavior patterns among lower-class families. The weight to be accorded any particular interest may vary with the several discrete family situations in which a stepfather figures: The mother may be widowed; the mother may be divorced, but the natural father may have disappeared, the natural father may take no interest in the child, or the child may be too young to have established a relationship with the natural father; or the mother may be divorced from a natural father who maintains (or wants to maintain) a continuing relationship with the child. Finally, a stepfather support obligation might be made concurrent with the natural father's duty or exclusive; his obligation could apply during his marriage to the mother or permanently. One of these variations, adopted because it is appropriate for one of the family situations, may be unwise or unacceptable for the others.

At first glance, a statutory stepfather support obligation seems to be a laudable and sensible goal. Family law policies should in part reflect existing family behavior patterns which are socially approved; since most stepfathers support their stepchildren, why should a small nonconforming minority be permitted to take advantage of a loophole in the statutory framework? In addition, family law doctrine should strive to coalesce the new family and encourage its continuity and permanence. Following a divorce, the mother almost always obtains custody of young children; ${ }^{40}$ the natural father's interest in his child-usually minimal even immediately following the divorce-diminishes gradually over time. ${ }^{41}$ Since the new family's cohesiveness would be fostered by minimizing the natural father's contacts, the stepfather should be encouraged 'to assume sole financial responsibility for the children. In short, the new family should be treated, to the extent possible, as if it were an integral and autonomous unit.

These family cohesiveness values can be fully realized, of course, only

39 tenBroek, supra note 36 , at 479 .

40 GoOde, AFTer Drvorce 311-12 (1956) (close to ninety per cent of mothers obtain custody following divorce in the jurisdictions where data available).

41 Id. at $315-16$. 
if the stepfather's support obligation is exclusive. If the natural father's support responsibility is to be terminated in order to minimize his contacts with the clildren, lowever, any possible loss to the child's financial interests must also be considered. If the mother is a widow the clild's financial position cannot be damaged, and may be enhanced, by transposing the stepfather's customary behavior into a formal obligation. Even if the mother is divorced, the child may not lose very mucli: Following a divorce, the natural father's maintenance of support responsibility often runs a course parallel with his personal interest in the child. ${ }^{42}$ Yet many natural fathers do maintain post-divorce financial responsibility for their children. An exclusive stepfather support rule would sacrifice the financial interests of these children; under current doctrines, the child lias the advantage of the stepfather's informal support without losing the insurance policy whicl his natural father's income represents. To be sure, the child will probably be seriously penalized in only two situations: if the natural father's income is much greater that the stepfather's; or if the child's needs require large expenditures whicl are beyond the stepfather's means but not beyond the joint resources of the stepfather and the natural father.$^{43}$ Can we say, with any assurance, that the family cohesiveness values promoted by an exclusive stepfather support obligation justify requiring the child to take liis financial chances with his stepfather in all cases? Without any data, it is easy to overestimate the extent to whicl the natural father's support responsibility may interfere with the new family's cohesiveness in those cases where the natural father does pay support. Since the natural father's payments directly or indirectly benefit the stepfather and mother as well as the child, continuing the natural father's obligation is not likely to disturb them. If the natural father simply pays support but takes no other interest, the child can probably be shielded from any hostility between lis mother and natural father which financial controversies inevitably produce. The new family will be disrupted, then, when the natural father's contacts are personal rather than financial; yet an exclusive stepfather support obligation would not eliminate the contacts of a natural father who wants to maintain personal ties with his child.

A substantial body of statutory and judicial doctrine suggests that the natural father's interest in maintaining a personal relationship with

42 See KApLAN, op. cit. supra note 38, at 16 (almost ten per cent of husbands of ADC mothers imprisoned for criminal nonsupport).

43 The child will only be penalized, of course, if the natural father will not contribute unless compelled to do so by a court order which relies on the natural father's statutory obligation. But these are the natural fathers (and the stepfathers) with whom a statutory obligation is designed to deal. 
his child, despite the mother's remarriage and his own, is both important and socially approved. The noncustodian natural father has been permitted, even encouraged, to maintain a continuing relationship with the child. The natural father's visitation rights have been denied only under the most extraordinary circumstances. ${ }^{44}$ Indeed, some courts have even refused to require support payments from the father if the mother willfully interferes with his visitation rights. ${ }^{45} \mathrm{~A}$ common statutory provision requires the natural father's consent to an adoption of the child by the stepfather. ${ }^{46}$ The natural father also retains some measure of his parental authority prerogatives. ${ }^{47}$ It is certainly not socially desirable, even if it were politically possible, ${ }^{48}$ to refuse to safeguard the natural father's affectional relationship with the child.

44 Commonwealth ex rel. Lotz v. Lotz, $188 \mathrm{~Pa}$. Super. 241, 244, 146 A.2d 362, 363-64 (1958), aff'd, $396 \mathrm{~Pa} .287$, 152 A.2d 663 (1959): "A parent has seldom been denied the right .... The cases in which visitation rights of a parent have been limited or denied have been those in which severe mental or moral deficiencies of the parent have constituted a real and grave threat to the welfare of the child. . . The courts bave granted visitation rights to parents even in those circumstances where the parent has ignored the children for a long period of time."

45 Snellings v. Snellings, 272 Ala. 254, 130 So. 2d 363 (1961) ; Annot. 95 A.L.R.2d 118, 134-42 (1964). This seems to be the minority view unless the mother removes the children from the jurisdiction of the court. See Foore, LEVY \& SANDER, op. cit. supra note 32, at 923-24.

46 See, e.g., MnNw. Stax. ANn. \& 259.24(1) (Supp. 1965); In re Parks, 267 Minn. 468, 127 N.W.2d 548; Note, 49 MrNN. L. REv. 128 (1964).

47 To be sure, the stepfather is the child's effective custodian and for many purposes he exercises parental control; but a court usually retains jurisdiction to circumscribe the stepfather's discretion at the behest of the natural father, or even to terminate the stepfather's authority by returning the child to the natural father's custody. Consider a hypothetical case: Following the parents' divorce, the mother obtains custody of the child; she marries a Christian Scientist and announces that she has converted to the stepfather's faith; the natural father requests the court's aid to insure that the child will not be denied necessary medical care. It would be difficult to refuse the natural father some say as to the manner in which his child is being raised. The court might estop a natural father who has not taken a continuing interest in the child prior to the contest; the court might adopt a narrow "scope of review" in supervising the stepfather's authority. But these protective devices would not ehninate the natural father's ability to intervene. Cf. GoldsteIN \& KaTz, THE FAMIIY AND THE LAW 183-216 (1965). The commentators suggest that there is "a relation between the father's right to the cutody and services of his minor child, and his duty to support the child." MADDEN, op. cit. supra note 31 , at 387 . If the natural father's support payments are to be used for a particular purpose (for example, parochial school tuition), perhaps he should play a more substantial role in the decision-making process on that issue. But the contrary need not be true-if the father is not paying support because of circumstances beyond his control, his role should not be circumscribed. It seems proper to determine the natural father's ability to intervene in accordance with the scope of his continuing interest in the child-evaluating a number of factors including his performance of support obligations.

48 The legislative conmitment underlying the adoption statute referred to in note 46 supra suggests that the natural father's interest is both important and socially approved. The judges apparently concur. The Supreme Court of Minnesota, for example, recently 
Yet preserving the relationship jeopardizes the cohesiveness of the new family unit. Visitation by the natural father frequently produces violent controversies. The natural father's contacts with the new family would be minimized, to be sure, if his visitation rights were protected without imposing a support obligation on him. But it is doubtful that providing an additional topic - the natural father's support paymentswould contribute substantially to the frequency or unpleasantness of the quarrels. Moreover, the stepfather's interests and feelings must also be considered. It will not be easy for the stepfather to accept the idea that he is in all respects the child's father-whether or not he wants the roledespite the fact that the natural father can invade his family's privacy and can challenge his authority over the child. ${ }^{40}$

If the stepfather's obligation to support the child is to be exclusive, finally, his obhigation should be made permanent. It hardly seems fair to require the natural father to plan his financial affairs to take account of the possibility that the mother's new marriage may end in divorce. It is true that the natural father's responsibility would theoretically be less onerous than it now is. Yet if the natural father remarries and acquires a family, there is no reason to penalize his second wife and family when

circumscribed the scope of a statute which authorized adoption without the consent of a natural parent "who has lost custody of the child through a divorce decree." MinN. STAт. ANs. $\S 259.24$ (1) (b) (Supp. 1965). Ordering dismissal of a stepparent's adoption petition, the court commented: "The correlative rights and duties inherent in the parent-child relationship are natural rights of such fundamental importance that it is generally held that parents should not be deprived of them 'except for grave and weighty reasons.' In an adoption proceeding, where an absolute severance of this relationship is sought, the consent provisions are designed to protect the natural rights of a parent to the custody, society, comfort, and services of the child. . . [W]e believe that the legislature intended that more than the mere existence of custody in one divorced parent is required to dispense with the necessity of consent by the other parent. ... [The statutory words] imply not only that custody must be granted exclusively to one parent but also that the right of the other parent thereto be lost, forfeited or extinguished ...." In re Parks, 267 Minn. 468, 475, 127 N.W.2d 548, 553 (1964). (Footnotes omitted.)

49 These arguments suggest that the natural father's support obligation should be eliminated only in those situations in which there is a sufficient interest in the step-family's cohesiveness to warrant cutting off the natural father completely. For children who are very young when the mother remarries, such a rule might well be justified. This is not to suggest that such a policy would command enthusiastic legislative approval. Sce notes $46-48$ supra and accompanying text.

Direct judicial enforcement of an exclusive stepfather support obligation may have unique disadvantages. Enforcement is likely to be necessary only against irresponsible stepfathers-those who might also be willing to forsake their families in order to evade a support order. In any event, family disputes which focus on the frequently delicate relationship between the stepfather and his wije's children will hardly be pleasant. If the natural father is available, it may be more sensible to pit the mother against him; in these disputes, at least, the stepfather and mother will not be adversaries. 
his first wife does obtain another divorce. ${ }^{50}$ And it would surely be inappropriate to establish a framework which might deprive the child of support from both his natural and surrogate parent. It would be more efficient and rational to apprise the stepfather that when he marries a divorced mother he incurs permanent responsibility for both mother and children. It is not at all clear, however, that it would be wise or politically possible to impose a permanent support obligation on stepfathers. If compelling the stepfather to support does in fact lessen remarriage opportunities for mothers, making the obligation permanent-in effect, disregarding the possible instability of the marriage-would maximize its deterrent effects. Many legislators who would have no objection to a stepfather support duty during the marriage would be unwilling to impose continuing responsibility on the stepfather for "someone else's kids" if he and the mother were to obtain a divorce. ${ }^{51}$ Notions of the sanctity of blood ties have operated often enough to the stepfather's disadvantage- the cases in which the stepfather seeks the child's custody following the mother's death provide one good illustration ${ }^{52}$-and there is no reason to believe that judicial attitudes are likely to change. It does not seem unfair to apply these notions evenhandedly. In addition, since the mother has an interest in assuring continuity of support for her children, her not inconsiderable persuasive powers as a wife may be more

50 This may happen under the current system, of course, especially if the court has reduced the natural father's support obligation when the mother remarried. But at least the natural father is on notice; and if he has some continuing obligation to his first family, he and his second wife will-or should-take his obhgation into account in choosing a standard of living. There is some evidence, albeit inconclusive, that remarriages are less stable than first marriages. See FooTe, LEvY \& SANDER, op. cit. supra note 32, at 771 n.70.

51 The English statute, imposing a support obligation on a parent for any "child of the family," enacts such a system. See Matrimonial Proceedings (Children) Act, 6\&7 Eliz. 2, c. 40, pt. 1, § 1 (1958):

(1) Subject to the provisions of this section, section twenty-six of the Matrimonial Causes Act, 1950 (which enables the High Court to provide for the custody, maintenance and education of the children of the parties to matrimonial proceedings), shall apply in relation to a child of one party to the marriage (including an illegitimate or adopted child) who has been accepted as one of the family by the other party as it applies in relation to a child of both parties.

(2) In considering whether any and what provision should be made by virtue of the foregoing subsection for requiring any party to make any payment towards the inaintenance or education of a child who is not his own, the court shall have regard to the extent, if any, to which that party had, on or after the acceptance of the child as one of the family, assumed responsibility for the child's maintenance and to the liability of any person other than a party to the inarriage to mamtain the child.

52 See Foote, Levy \& SANDER, op. cit. supra note 32, at 853 . See also Note, Alternatives to "Parental Right" in Child Custody Disputes Involving Third Parties, 73 YaLE L.J. 151 (1963). 
effective in accomplishing an adoption than a statutory support obligation would be. If the stepfather's failure to adopt can be attributed to the mother's hesitance, however, it does not seem fair to require him to provide post-divorce support for the child. In any event, the child can be protected to some extent without enacting an inflexible stepfather support provision: In most states the mother is entitled to support from her husband after a divorce, and the judge can informally take her children (and the natural father's circumstances) into account in determining the amount of ahmony to which sle is entitled. ${ }^{63}$

Imposing joint support obligations on both stepfather and natural father avoids some of the difficulties of an exclusive stepfather obligation. The stepfather's responsibility would not have to be permanent; and the child would not lose the benefits of two sources of support-at least while the mother's second marriage lasts. On the other hand, if the natural father is currently paying support, the system would have disadvantages as well. Some nethod would have to be devised to allocate responsibility between the natural father and stepfather. In the process, the child might come out the loser. Currently, the natural father's support payments are theoretically figured without regard to any benefits the stepfather provides the child. If the stepfather is legislatively recognized as a source of support for the child, his income will have to be taken into account in determining the amount of the natural father's payments. Of course, under present doctrines the court can reduce the natural father's decree obligation when the mother remarries; ${ }^{54}$ but the pressures to reduce the natural father's support payments will inevitably be-indeed, should be-greater if the stepfather has a concurrent statutory support duty. If the natural father is taking an interest in the child as well as paying support, a formal stepfather support duty does not seem important enougly to incur the costs of administering the system.

53 For a recent case in which the court's separate maintenance award apparently took the wife's child by a previous marriage into account, see Johnson v. Davis, 140 N.W.2d 703 (N.D. 1966). The wife will probably obtain less money if the judge is disguising support payments in an alimony award. In community property states such as Califormia, of course, upon divorce the wife generally has an immediate right to half of the assets which the husband has acquired with earnings during the marriage. During the marriage, however, the wife probably cannot obtain, in either common law or community property states, judicial aid in obtaining support from her husband. FOOTE, LEVX \& SANDER, op. cit. sicpra note 32 , at $303-13,317-23$.

54 Cf., e.g., Commonwealth v. Camerson, 197 Pa. Super. 403, 179 A.2d 270 (1962) (release by custodian mother and stepfather of natural father's support obligation effective in absence of evidence that stepfather and mother cannot afford to support the child). See also Whybra v. Gustafson, 140 N.W.2d 760 (Ct. App. Mich. 1966) (support order against father of illegitimate child not an abuse of discretion, despite fact that amount was only half that proposed under uniform schedule used by judge as guide in divorce cases, because mother had married and child is now part of three-child household). 
There is no reason to exacerbate already unedifying and unpleasant judicial controversies by adding issues such as the relative affluence of the natural father and the stepfather. It may not be possible to avoid bitterness between the mother and the natural father-bitterness which will have an effect on the child's contacts with the natural father. It hardly seems wise to insure the stepfather's active participation in the battle. To the extent that the natural father has reason to resent the stepfather, the child's relationship with the stepfather is likely to suffer. Since a great many natural fathers absent themselves and refuse to pay support, ${ }^{65}$ the stepfather's obligation might be drafted to apply only when the natural father is either unable or refuses to pay support. Even this standard could produce serious problems of administration. The stepfather's hability would turn on the natural father's "abandonment" of the child, or on some equally vague standard for determining when the formal duty shifts. The issue would have to be relitigated in each support action brought against the stepfather; and the standard might encourage a bitter stepfather to make efforts to haul the natural father back into the controversy.

If we had some basis for predicting that stepfathers who do not now support their stepchildren during the marriage would do so if a formal support obhgation were enacted, if we could say with assurance that enacting a joint support obligation would not modify present patterns of adjustment between stepfamilies and natural fathers because most natural fathers maintain neither personal nor financial interest in their children, there would be no reason not to impose a joint support obligation on the stepfather. But these imferences cannot be drawn at present; and, taking into account all the possible family contexts in which the rule would have to be applied, a stepfather support obligation might well produce more problems in some contexts than its value in the others justifies. ${ }^{56}$ It may be wiser simply to rely upon the mother's interest in her children's financial security and her ability to persuade the stepfather to adopt the children. ${ }^{57}$

\footnotetext{
55 See authorities cited in notes 38 and 42 supra.

${ }^{56} \mathrm{~A}$ stepfather support obligation is most clearly justified when the mother is widowed. The child's interests-financial as well as familial-would be served by encouraging the stepfather to adopt him. Since that is true, it does not make sense to make the status of stepfather too attractive. The stepfather is free to adopt the child, if the mother is willing, and no interests inconsistent with achieving maximum cohesiveness and permanence for the new family have to be protected. But cf. In re Guardianship of Woodward, 102 N.Y.S.2d 490 (Surr. Ct. 1951) (stepfather and paternal aunt estabhished as joint personal guardians of wealthy child following mother's death; child's wealth derived from paternal grandparents; paternal grandparents and paternal aunt had contested stepfather's prior effort to adopt the child).

57 The stepfather will usually be able to adopt if the natural father has "abandoned"
} 
As we have already suggested, it is most difficult to accommodate all the conflicting interests, take account of the various contexts in which the issues may arise, and still formulate a sensible and flexible statutory support policy for stepfathers. We can be sure that a stepfather support statute would create new and difficult problems; since most stepfathers probably support the children during the marriage without a statutory duty, it does not seem unreasonable to prefer the status quo.

\section{2. "Men in the House"}

Stable, nonmarital family relationships present a different problem. Theoretically, a common law marriage, ${ }^{58}$ despite the informality of its formation, is no different than the ceremonial variety; a common law husband has support obligations, his subsequent marriage without a divorce is bigamous, his wife is entitled to a widow's rights at his death. ${ }^{50}$ In fact, however, the common law marriage doctrine makes sense only as a fictional, ex post facto method of preventing injustice to women and children who were members of a stable and viable family until some unforeseen event made proof of a valid marriage essential: The father dies or is killed, perhaps, and the mother or children file a wrongful death action, claim workmen's compensation benefits or the father's insurance policy, or seek social security benefits. ${ }^{60}$ The man who might subsequently be considered a participant in a common law marriage is for all practical purposes free to leave his family whenever he wishes. ${ }^{61}$ This is

the child. See authorities cited in note 46 supra. It is probably true that "abandonment" may be rigorously construed if the natural father appears to contest the adoption. $C f$. authorities cited in note 52 supra. The only situations posing a serious problem are those in which the natural father has an interest in the child but no money, and the stepfather has money but is unwilling to support the child. We wonder whether such situations frequently occur.

58 For a description and analysis of the concept, see Weyrauch, Informal and Formal Marriage-An Appraisal of Trends in Family Organization, 28 U. CHr. L. REv. 88 (1960). For a criticism of the doctrine, see Kirkpatrick, Conmon-Law Marriages: Their Common Law Basis and Present Need, 6 ST. LouIs U.L.J. 30 (1960).

59 See MADden, op. cit. supra note 31, at 39-40.

60 See generally FooTe, LEvx \& SAINDER, op. cit. supra note 32, at 272-94.

61 It is true that the common law marriage issue may arise when the marriage is a going venture, e.g., when one of the parties seeks separate maintenance, a divorce, or some other benefit of a legal marriage. See Colbert v. Colbert, 28 Cal. 2d 276, 169 P.2d 633 (1946) (separate maintenance action by common law wife who had divorced husband to evade rule prohibiting spouses to work in same agency; couple had continued to live together). Nonetheless, the great majority of appellate cases are of the type described in the text. It seems likely that if the issue is the common law husband's continuing support responsibility for his common law wife, the courts would at least require much more persuasive evidence of the "marriage." Cf. Ex Parte Threet, 160 Tex. 482, 333 S.W.2d 361 (1960). And the husband could always deny that he had performed the ritualistic formalities necessary to formation of a common law marriage. 
certainly the most common method of dissolving even relatively stable "common law marriages":

For many people at the lower end of the economic scale, divorce, the minimum cost of which in California is generally about 200 dollars is a luxury beyond their financial means. When poor families break down, the husband simply leaves. Desertion has become known as "the poor man's divorce."

Under these circumstances, does it make any sense to impose a support obligation on such "husbands"? If the mother and father are not married, the paternity action permitted in most states will probably accomplish as much for the children as a support statute would; ${ }^{63}$ if the parents' marriage is "void," either a legitimation statute or a paternity action statute will safeguard the children's right to support. ${ }^{64}$ The problem, then, concerns only the "common law" husband who is not the children's father. Considering the difficulties of the task, imposition of a support obhgation on such "men in the house" should not be undertaken.

Since such relationships will most frequently be found among poor families, the children will probably not be able to look to the natural father for support. If our major concern in these situations is the availability of welfare benefits, however, family law doctrines need not be modified. ${ }^{65}$ Nor should we meddle with the system if the effort will be a waste of time: Some of the "husbands" served with complaints in support actions under these circumstances will undoubtedly "divorce" their spouses on the spot. ${ }^{66}$ Equally important, framing a support policy for these situations would involve enormous practical and policy problems.

The legislature can extend ex post facto recognition to stable family relationships with little concern that the legislation will encourage their proliferation; nor does it seem likely that refusing ex post facto recogni-

62 See tenBroek, 17 Stan. L. Rev. 617. See also Foster, Common Law Divorce, 46 MINN. I. REv. 43 (1961).

03 See Foote, LEVy \& SANDER, op. cit. supra note 32, at 46-53.

64 Id. at 32-34.

05 In fact, utilizing family law doctrines to accomplish welfare purposes may be selfdefeating. It is not unlikely that the demise of the common law marriage doctrine, see note 68 infra, is due in part to its frequent use in welfare contexts. See note 60 supra and accompanying text. Certainly employers who contribute to workmen's compensation funds have often lobbied for legislative abolition of the doctrine.

${ }^{60}$ But cf. Paulsen, Juvenile Courts, Family Courts, and the Poor Man, this symposium. If there is proof that the "man in the house" has exchanged verba de praesenti and met the other formalistic prerequisites of a common law marriage, and if a common law marriage is not only an ex post facto saving device but a marital status binding for all purposes, then imposing a support obligation might be appropriate. But see note 67 infra and accompanying text. 
tion would deter very many people from forming stable, nonmarital relationships in the future. Yet a legislator may properly balk at providing a statutory support obligation lest it imply approval of such methods of family formation. ${ }^{67}$. A support obligation can hardly be recognized in the states which have abolished the common law marriage doctrine. ${ }^{08}$ Moreover, how could a fair support statute be drafted? It does not seem appropriate to require support from a casual paramour; and the prerequisites to liability-indicia of family status such as the stability of the relationship-would have to be phrased in the vaguest terms. ${ }^{69}$ The most sensible course is to permit these informal families to resolve their financial problems by self-hielp.

\section{Stepfathers}

\section{B. Welfare Policy}

In determining a child's eligibility for AFDC benefits, should the earnings of a stepfather be taken into account? The California statute, ${ }^{70}$ and regulations in a number of other states, ${ }^{71}$ make his income relevant. Dr. Bell commented:

So long as the evidence genuinely supported the conclusioin that a man lived continuously in the home or was considered by the family to have the status of "father" and "husband" there may have been little logical basis for distinguishing such a family from those with two able-bodied legally married parents who were excluded until 1961 by Title IV of the Social Security Act, and also until the present time from numerous state and local general assistance programs, particularly in Southern states. ${ }^{72}$

We hold no brief for tying assistance benefits to rigid categories-permitting payment for physical but not for mental or emotional defect, or authorizimg benefits when an incapacitated father is in the home but denying them if the father is simply unemployed. Yet it would be im-

${ }^{67}$ Cf. Schwartz, Book Review, 96 U. PA. L. REv. 914, 915-16 (1948). In any event, although it may be sensible for the legislature to extend to an informal family relationship which has in fact been permanent all the perquisites of a valid ceremonial marriage, the legislature need not treat the relationship as binding for all purposes. It may be wiser to permit couples who have begun a family relationship informally to terminate their relationship in the same fashion.

68 Only about fifteen jurisdictions continue to recognize common law marriages. Fooxz, LEVY \& SANDER, op. cit. supra note 32 , at 270 . A number of states which have abolished common law marriages continue to recognize one or more of the other ex post facto saving devices designed to prevent injustice to a participant in an invalid marriage. Id. at 278-94.

69 If no support obligation is imposed upon stepfathers, of course, it would be much more difficult to justify a "man in the house" support obligation.

70 Cad. WeLfare \& INST'Ns Code § 11351.

71 Bext, Am to Dependent Chutdren 76 (1965).

$72 I d$. at 86 . 
possible to obtain widespread support for an assistance program which ignored the earnings of a natural father. Indeed, only strongly felt notions of parental responsibility can explain the original ADC program's exclusion of a child whose "able-bodied" natural father is a member of the family. ${ }^{73}$ These notions operate today. When the 1961 Social Security Act amendments broadened the program to include families with an unemployed father in the home, ${ }^{74}$ "Congress imposed conditions designed to stimulate the employment or enhance the employability of that parent-that is, to eliminate his idleness and lack of visible means of support." ${ }^{\prime 75}$ And the amendments permitted the states to continue pre-1961 policies. $^{76}$ It is perfectly natural that legislators would hesitate to adopt a program which miglit encourage lazy fathers to rely solely on the public to support their families-their concern is appropriate so long as it does not become an obsession. The Bureau of Public Assistance construed the original ADC provisions to permit exemption of the stepfather's income in determining a child's eligibility-apparently because a stepfather has no statutory obligation to support the child. ${ }^{77}$ Yet if the Congress did not want to encourage lazy natural fathers, it sliould be equally opposed to encouraging lazy stepfathers. The issue, then, is whether stepfathers should be treated differently than are natural fathers when public funds are at stake.

There are practical reasons for taking the stepfather's income into account. If one factor to be considered in devising welfare programs is mimimizing public expense without undermining the program's purposes -and, for better or worse, everyone seems to agree that cost minimization has been a factor ${ }^{78}$ - the financially responsible stepfather cannot be ignored. Even if total program cost increments are irrelevant, sound welfare administration requires that the stepfather's solvency be considered. To the extent that the absolute number of beneficiaries can be minimized without unfairness, it may be possible to increase the rather

73 BEII, op. cit. supra note 71, at 1-19, traces the history of the ADC program, and the "suitable home" policies which have been a part of it, to the Mothers' Pension programs of the 1920's. "The only families who were eligible [for a Mothers' Pension] in all states, though, were those whose fathers had been permanently eliminated by death, long-term imprisonment, or incurable insamity. In this way the twin headaches of nonsupporting fathers and immoral mothers were largely avoided." Id. at 9, See also $i d$. at 80.

7475 Stat. 75 (1961), as amended, 42 U.S.C. \$ 607 (1964).

75 Rosenheim, Vagrancy Concepts in Welfare Law, 54 CAIIF. L. REv. 511, 531-32 (1966). 76 BELL, op. cit. supra note 71, at 86.

77 Bureat of Public Assistance, Social Security AdMINISTration, Handbook or Public Assistance Administration, Part IV, 3400-99 (Nov. 4, 1946), cited in Beli, op. cit. supra note 71 , at 77 n.2. Dr. Bell suggests that the Bureau's rule was based upon the fact that the stepfather might have no duty to support the child. Ibid.

78 E.g., BELL, op. cit. supra note 71, at 60-67; tenBroek, 17 STAN. L. Rev. 676. 
paltry sums which beneficiaries now receive without additional appropriations. In addition, the incidental consequences of refusing to consider the stepfather's income may be unfortunate. If the mother is receiving benefits, the welfare department must seek recompense from the natural father; ${ }^{70}$ if the natural father has established a new family, it may be socially more advantageous to permit the natural father to devote his funds to his new family so long as the stepfather is able to provide support. This is certainly true of families with marginal incomes. To be sure, the stepfather and mother may seek support from the natural father if AFDC benefits are cut off. But it is not unreasonable to assume that the mother and stepfather will pursue the natural father less relentlessly than the welfare department would.

More basic considerations also suggest that the stepfather's income should be counted in determining eligibility. One need not be bigotedagainst the poor or other minority groups-to believe that welfare programs should encourage stepfathers to assume the support responsibilities which a natural father would be compelled to assume and which, as we have already indicated, many stepfathers voluntarily assume. A "substitute parent" rule will certainly encourage some stepfathers to support the children in their homes. On the other hand, a stepfather who can rely upon a monthly AFDC payment may not be as willing to devote his income to maintaining his wife's children. He might also be encouraged not to adopt the children, since his family's government bonus would then terminate. Indeed, there have been cases (in the welfare department records of at least one jurisdiction which did not at the time have a "substitute parent" rule) in which stepfathers have been urged not to adopt lest AFDC benefits be lost. ${ }^{80} \mathrm{~A}$ "substitute parent" rule might encourage some stepfathers who obtain employment to divorce their wives; but are the divorce risks more substantial than the irresponsibility we encourage by exempting the stepfather? A "substitute parent" rule may encourage some stepfathers to stay unemployed; but is avoiding this disincentive more important than treating the stepfather's income as we would the natural father's income?

In short, any policy is likely to produce some undesirable side effects; the importance of the goal we seek must be weighed against the magni-

79 For a description of the famous "NOLEO" amendment, Social Security Act Amendments of 1950 , ch. 809 , § 321,64 Stat. 550 , see BEIL, op. cit. supra note 71, at 80 . The amendment requires the welfare department to notify the responsible law enforcement official whenever aid is granted to a child who has been abandoned by his parent.

80 One of the authors, in the course of a study of a state welfare department's investigations of "independent placement" adoptions, found several reports recommending that the court deny stepfather petitions because the children would lose their ADFC benefits if they were adopted. 
tude of the undesirable consequences which inevitably accompany any method chosen to attain it. The only risk we take in approving a "substitute parent" rule is that a substantial number of marginal income stepfather families which are stable and providing a good and healthy environment for the child with a government income supplement would become unstable and less adequate for the children without the supplement. Obviously, we have not begun to explore the magnitude of this risk. There is probably agreement that benefits should not be given to wealthy stepfathers. We might indulge in the assumption that only poor step-families would seek benefits. Yet many stepfathers who do not need the money seek support payments from natural fathers who are in similar financial circumstances. Are the prospective benefits of making AFDC payments available to marginal income step-famikes worth the risk that some step-families which do not need the money will profit as well ${ }^{81}$ If the stepfather's income is not marginal, of course, the child may profit more in the long run if the stepfather is not discouraged from adopting him. In the absence of any reliable evidence as to the effects on family stability of either rule, we believe that the stepfather's income slould be taken into account; the risks we have suggested do not seem sufficiently substantial to warrant eliminating a policy which encourages, even indirectly, financially able stepfathers to support their families.

\section{2. "Men in the House"}

The "man in the house" rule authorizes the welfare department to consider the income of a "male person assuming the role of spouse to the mother although not legally married to her"82 in determining a child's eligibility for AFDC benefits. The rule has produced violent controversy. It seems hikely, however, that much of the opposition has been occasioned by use of the rule to regulate the out-of-wedlock sexual behavior of AFDC mothers:

[T] he "nonstable, nonlegal" union in Arkansas, the "male boarder" in Michigan, "Roger the Lodger" in Oregon, the "unrelated mau living in the home" in Alabama were examples of a rather tenuous relation-

81 Well-to-do stepfathers might feel too embarrased to claim welfare benefits. Or they might not want to submit to the caseworker supervision which is an inevitable concomitant of the grant. One might question whether it is sound to rely on these deterrents, at a time when so much is being heard about the "right" to benefits. See Handler, Controlling Official Behavior in Welfare Administration, this symposium. In any event, if stepfather families with marginal income may be unstable without a government financial increment, it is just as likely that natural father families, similarly situated, will be unstable. If stepfathers are to be helped, why not help natural fathers also? Of course, if the natural family breaks down, the natural father retains a formal support obligation; but that hardly provides security for the children. See authorities cited in note 38 supra.

82 CaL. Welfare \& InsT'Ns Code $\$ 11351$. 
ship where there was no necessary presumption of a consistent or acknowledged relationship and evidence of the man's existence was sometimes so insubstantial or transient that he was dubbed the "phantom father" in one study. ${ }^{83}$

We are concerned only with the stable and openly acknowledged family relationships contemplated by the rules of the California Department of Social Welfare:

a. He is im or around the home and is maintaining an intimate relationship with the mother, or is the father of one or more of the children, and

b. He has assumed substantial financial responsibility for the ongoing expenses of the ANC family, and/or

c. He has represented himself to the community in such a way as to appear in the relationship of husband and/or father.

The existence of items a plus $b$ and/or $c$ creates a rebuttable presumption that the adult male has assumed the role of spouse. ${ }^{84}$

The rule recognizes (as does Professor tenBroek) ${ }^{85}$ that in a society which includes many cultures and a substantial group of poverty-stricken individuals many perfectly stable informal families will inevitably be found. For some couples a "common law" understanding is a customary and acceptable alternative to a rehgious or civil ceremony. If welfare benefits are denied to families in which a legally married father's earnings are above the assistance level, is there any reason to treat the "common law" husband and father differently? In one of his earlier articles Professor tenBroek remarked:

Viewed in welfare and financial terms, this family situation and the needs of the children would not be different if the man and woman were married according to all the conditions set down in the Civil Code. Yet if stepfather liability is not imposed [on common law stepfathers], the children are eligible for aid to needy children regardless of the man's income. A financial premium is consequently placed on the common law relationship, and inequity is sanctioned between common law and duly married stepfathers, and a line of distinction

\footnotetext{
83 BEI, op. cit. supra note 71, at 86 .

84 tenBroek, 17 Stan. L. Rev. 620, quoting CaL. AFDC Manuex, Reg. § C-155. A disclaimer may be necessary. We would not imply approval of these factors as compared to others which might be phrased. We would not minimize the difficulty of the definitional task, nor the risks of maladministration of an appropriate standard-especially in those Southern states which seem to be pursuing inıproper goals. See BELI, op. cit. supra note 71, at 93-110. It may well be that more flexible safeguards than those presently available to the Federal Bureau of Family Services must be devised to protect against such risks. Id. at 186-94. But these are not arguments against some form of "man in the house" rule.

85 See tenBroek, 17 Stan. L. Rev. 617, 619. See also People v. Shirley, 55 Cal. 2d 521, 525, 360 P.2d 33, 35, 11 Cal. Rptr. 537, 542 (1961).
} 
is drawn between the two which has hittle bearing upon the financial program of aid to needy children. ${ }^{86}$

We do not want to be misunderstood. We are not urging a morality crusade. Rather, we see the rule simply as a method of eliminating an evasionary device. If a stepfather rule is adopted, a "man in the house" rule is a necessity-so that couples will not be encouraged to live together without marrying in order to continue the mother's AFDC benefits. The more inclusive rule is especially important in jurisdictions in which substantial populations feel little cultural compulsion to engage in ceremonial ("legal") marriage. ${ }^{87}$

The "mian in the house" rule may accomplisl what it was designed to accomplish-financially able "fathers" will remain in the home and will support the children. ${ }^{88}$ We sliare Professor tenBroek's doubt, however, that in every case "it is reasonable to infer that a man assuming the role of. spouse will contribute to the support of the mother and lier needy child." We also doubt the effectiveness of the circumscribed support obligation appended to the California "man in the house" rule: "[S]uch adult male person is bound to support, if able to do so, his wife's children if without support from such . . . adult male person they would be needy children eligible for aid under this chapter." effective sanction will probably be the mother's threat: "Support me and the kids, or out you go!" If slie does not threaten, and the children suffer, the community can intervene through the processes of the juvenile court. $^{91}$ If the mother makes use of lier sanction because her AFDC benefits are at stake, the "man in the house" rule may have a "deterrent effect on stable common-law unions providing a two-parent home for the child by the withdrawal of the premium." But the only men (who have or can obtain decent employment) likely to be influenced by the rule are: (1) those who would rather use their own income on themselves to the exclusion of their families, and (2) those who would be tempted to desert their families simply because the taxpayers' contribution to the

86 tenBroek, The Impact of Welfare Law Upon Family Law, 42 CAIT. L. REv. 458, 483 (1954).

87 "[C]ommon law marriage is an accepted custom among many Mexican families at the lower socio-economic level and is a legally recognized form of marriage in Mexico." tenBroek, 17 Stan. L. REv. 617.

88 "The truth is that the rule was adopted not 50 much as a measure of contributions actually being made as it was a means of seeing to it that contributions were made." Id. at 657.

89 Id. at 658 n.999.

O0 CAL. WELFARE \& INST'NS CODE § 11351.

91 See generally Foote, Levy \& SANDer, Cases on Faxint Law 400-22 (1966).

02 tenBroek, 17 STAN. L. REv. 658 n.999. 
family's imcome is eliminated. We wonder whether it is socially useful to encourage the stability of such two-parent families. We do not know, it is true, that children will develop more favorably without a "father" than they will with a financially able "father" who refuses to support them. But we have no reason for believing the contrary. In any event, the only way to eliminate the deterrent effects of the rule would involve placing a "financial premium" on informal relationships. Since we must either encourage or discourage the stability of these families-we are not discussing immoral families, let us repeat, but families whose stability is based solely on the continuance of a governmental income incrementit does not seem improper to adopt the course suggested by middle-class notions of family support.

\section{CONCLUSION}

We will not be disappointed if our analyses of these family law and welfare policies produce disagreement. Indeed, rational doctrinal formulation is aided by presentation and vigorous defense of a variety of inconsistent-even contradictory-proposals. But the process will be helpful only if the arguments are on the merits. Demands for "equality" which disregard essential differences in the doctrines chosen for comparison will provide little guidance to legislators. The fourteenth amendment, althougl it obviously imposes limitations on legislative discretion, cannot be considered the sole repository of either family law or public welfare wisdom. The issues can be clarified and resolved more cogently if family law and welfare policies are differentiated and examined with care. 